\title{
THE INFLUENCE OF COMBAT SIMULATION EXERCISES ON INDIRECT MARKERS OF MUSCLE DAMAGE IN SOLDIERS OF THE BRAZILIAN ARMY
}

\author{
A INFLUENNCIA DO EXERCÍCIO DE SIMULAÇÃO DE COMBATE SOBRE \\ MARCADORES INDIRETOS DE LESÃO MUSCULAR EM SOLDADOS DO \\ EXÉRCITO BRASILEIRO
}

\section{Norma Claudia de Macedo Souza SANTOS ${ }^{1}$; Eduardo Borba NEVES ${ }^{2}$; Marcos de Sá Rego FORTES ${ }^{3}$; Eduardo Camillo MARTINEZ ${ }^{4}$; Orlando da Costa FERREIRA JÚNIOR}

1. Farmacêutica, Mestre em Saúde, Medicina Laboratorial e Tecnologia Forense pela Universidade do Estado do Rio de Janeiro (UERJ), RJ, Brasil - ncfarma@gmail.com ; 2. Fisioterapeuta, Doutor em Engenharia Biomédica, Instituto de Pesquisa da Capacitação Física do Exército (IPCFEX), Rio de Janeiro, RJ, Brasil; 3. Educador Físico, Doutor em Clínica Médica, Instituto de Pesquisa da Capacitação Física do Exército (IPCFEX), Rio de Janeiro, RJ, Brasil; 4. Educador Físico, Doutor em Saúde Pública, Instituto de Pesquisa da Capacitação Física do Exército (IPCFEX), Rio de Janeiro, RJ, Brasil; 5. Médico, Doutor em Ciências Biológicas, Professor da Universidade do Estado do Rio de Janeiro (UERJ), RJ, Brasil.

\begin{abstract}
The combat simulation exercise is a military activity where combat activities characterized by intense physical activity are simulated. The aim of this study was to describe the behavior of indirect markers of muscle damage during military activities of combat simulation with the realization of strenuous physical efforts. This study was conducted with military recruits/volunteers $(n=43 ; 19-24$ age group) from the COMANDOS Army Corporal Training Course. The biomarkers were evaluated at the baseline (T0), 72 hours after the baseline (T1) and 63 hours after the end of the activity (T2). To compare the variables analyzed at different times, an analysis of variance (ANOVA) was applied to repeated measures with post hoc Tukey's test to identify the statistically significant differences. The criteria of significance adopted was the value of $\mathrm{p}<0,05$. On average, the total body mass was significantly greater in $\mathrm{T} 0$ when compared to $\mathrm{T} 1$ $(74,4 \mathrm{~kg}$ x $69,8 \mathrm{Kg} ; \mathrm{p}<0,05)$. In relation to the biochemical markers, on average, the serum levels were significantly higher $(\mathrm{p}<0,001)$ in T1 when compared to T0: CPK, LDH, CRP, Mb and AGPA. After 63 hours of rest, on average, the serum levels of the biochemical markers were significantly lower than in the moment T1: CPK, LDH, CRP, Mb and AGPA. However, after 63 hours of the end of the activity, all variables evaluated returned to baseline, with the exception of LDH, that on an average remained above the values observed in the moment T0. This study made possible to understand the behavior of indirect markers of muscle damage during the COMANDOS Army Corporal Training Course. However, others studies are necessary, regarding to Training Courses such as: paratrooper, mountain, jungle warfare and others to try establish a possible range of reference values for this markers during military activities.
\end{abstract}

KEYWORDS: Muscle damage. Indirect markers of muscle damage. Intense physical activity.

\section{INTRODUCTION}

Brazil's Military Army incentive the practice of military physical training among military organizations (MO), aiming at the development of physical fitness required for the performance of the various functions that the serviceman is subjected throughout his career, thus contributing to the maintenance of health and improvement of the attributes of the affective area, such as camaraderie and esprit de corps (BRASIL, 2015). In this context, several authors argue that subjects with adequate levels of physical fitness present high protection factor for several comorbidities and improvement in life quality (RICARDO et al, 2008).

During the period on active duty of a serviceman, one should be able to perform various functions and assignments inherent to his military training within the arms, frames and services (health professionals, administrative, operational, training, research and others), and to do so it is necessary that these servicemen must be in continuous preparing to develop their technical and professional skills (BRASIL 2006).

The Combat Simulation Exercise (CSE) is an instrument of evaluation, indispensable to the development of the attributes of the affective area (courage, emotional balance, decision, abnegation, initiative, self-confidence, resistance, cooperation and creativity). These attributes are necessary to the formation of a military character (BRASIL 2006).

For the present study, the CSE is a military activity conducted in an appropriate environment where combat activities are simulated involving: marches, tactical movements, maneuver of small combat groups, rescue simulation and transport of 
wounded, action planning and military maneuvers, among other activities inherent to combat (BRASIL, 2014).

In order to perform those activities, this serviceman must have a high degree of physical fitness, psychological control and develop throughout the preparation and training with increase of the progressive load, seeking cardio respiratory endurance improvement, strengthening of the musculature to prevent the risks of fractures, sprains and muscle damage (BRASIL, 2015) (AMERICAN COLLEGE, 2009).

Some studies (HILL; WAHI et al. 2012), (MAGALHÃES 2008) (MONTEIRO; BRUM et al. 2011) have reported cases where servicemen are suspects of triggering adverse outcomes of Rhabdomyolysis during the performance of exercises that present the same characteristics of CSE in relation to conditions of extreme exercises. Rhabdomyolysis is defined as a clinical and laboratory syndrome caused by skeletal muscle necrosis due to the release of intracellular substances to the circulation (ROSA NG et al ,2005).

The practice of intense exercise can result in muscle damage that can be evidenced by muscle pain of delayed onset, loss of strength, weakness, and increased blood levels of muscle proteins, including creatine phosphokinase (CPK), Lactate dehydrogenase (LDH), myoglobin (Mb), C-reactive protein (CRP), alpha 1-acid glycoprotein (AGPA) (TRICOLI 2001). The occurrence of muscle damage caused by overloads of physical activities is one of the main causes that may induce work leave of servicemen and may considerably heighten the cost of health treatments (PARR; CLARK et al. 2015).

The indirect methods adopted for muscle damage analysis are the most commonly used in studies due to easiness of collecting and, above all, due to its low cost when compared to direct methods (MRI and muscle biopsy) (BANFI; COLOMBINI ET AL. 2012). Examples of that are the dosages of creatine phosphokinase (CPK) and lactate dehydrogenase (LDH), enzymes involved in muscle metabolism and often found as muscle damage markers after strength training or intense physical activity. These enzymes are cytoplasmic and do not have the ability to cross the sarcoplasmic membrane barrier. Therefore, the increase in the serum concentration of these enzymes suggests that there was damage to the muscle membrane (ROSA NG et al, 2005), (BANFI; COLOMBINI et al. 2012).

There is no well-stablished knowledge about the behavior of muscle damage markers during intense military training activities, given that there is no universally accepted biomarker since it is multifactorial changes associated with individual physical fitness. Thus, clinical analysis become an important tool to serve as beacon, using modern techniques (auto analyzers and molecular biology) that can act as support for clinical diagnosis in outcome situations to several pathologies, such as rhabdomyolysis (Burtis, Ashwood et al. 2008 ). This knowledge can facilitate the identification of a referential pattern which should include the standardization between race, gender, age, biological variability and biochemical response to this type of activity (BRASIL, 2015), (BURTIS; ASHWOOD et al. 2008 ) and (HENRY 2012).

In this sense, the present study aimed to describe the behavior of the indirect markers of muscle damage during the military activities of combat simulation with the realization of intense physical efforts.

\section{MATERIAL AND METHODS}

This is an observational study performed with a population of 43 military recruits, male, aged between 18 and 23 years (median 19 years; 19-22, $\mathrm{P} 25 \%$-P75\%, respectively) volunteers to the COMANDOS Army Corporal Training Course (CACTC) from the 1st Command Action Battalion ( $1^{\circ}$ Batalhão de Ações de Comandos - BAC / GO), that were submitted to Combat Simulation Exercise - CSE (BRASIL, 2006). The CSE was carried out during June of 2015.

Initially, after the volunteers' compliance to participate in the research, Statement of Information to Institutions and Free and Informed Consent Form were signed. The study was approved by CONEP's (Conselho Nacional de Saúde) Ethics Committee with opinion $\mathrm{n}^{\circ} 1.220 .233$. Then, a lecture to the military troops from the 1st Command Action Battalion (ACB - GO), submitted to Combat Simulation Exercise (CSE), was performed, in order to inform them about the aims of the study, the methodology, the voluntariness to participate and also to inform them that the results would be disclosed within the Military Organization and the Department of Culture of the Army (Departamento de Ensino e Cultura do Exército - DECEx) to be widespread in the military doctrine of educational institutions.

All the volunteered servicemen that were considered fit after medical visit were included in this study. Though, the volunteers who requested to be disconnected (singular pretension) at any time of course were all excluded, along with the ones that, 
or for technical or physical or health failure did not meet the purposes of the training course.

\section{Study design}

Data collection happened in three moments

(Figure 1). The first was at the baseline (T0) before the beginning of the activities, the second was at $\mathrm{T} 1$ moment, after 72 hours from the baseline, and the third was at T2 moment, after 63 hours after the end of the military activity.

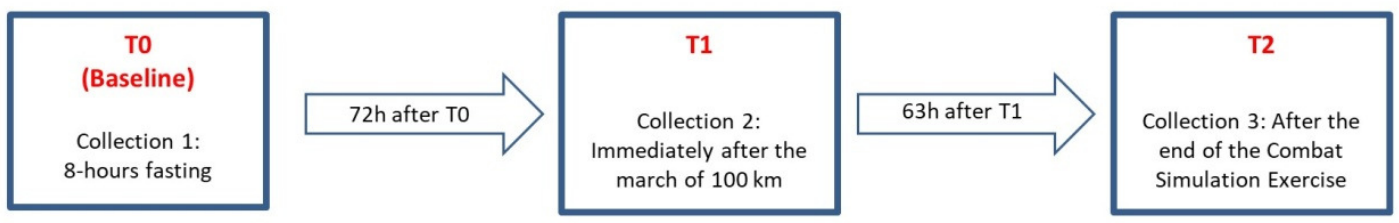

Figure 1. Study design

\section{CSE characterization}

The SCE was held after the 5th week of the beginning of the CACTC on the Actions and Command Battalion (ACB), MO subordinated to the Special Operations Command (Comando de Operações Especiais - COPESP) in the city of Goiânia, the course was distributed in 4 full days of 24-hour of continuous operations, where volunteers were evaluated on their leadership potential in combat, through the manifestations of the main attributes of the affective area: endurance, camaraderie, emotional balance, decision, abnegation, initiative, self-confidence, cooperation and creativity.

The intensity of the physical activity performed was monitored by means of distance traveled, measured by GPS, perceived exertion, by the adapted Borg Scale of 10 (BORG 2000) and the percentage of transported cargo. The cargo consisted of a backpack with an average weight of $25 \mathrm{~kg}$ containing uniforms, ammunition, items of personal use, annotation material, medical supplies, two canteen filled with water, rifle weapons $7.62 \mathrm{~mm}$ and a machete. Besides that, they also shared the transport of a machine gun Mag model, and also communication material that were carried in turns by all members of the patrol during the $25 \mathrm{~km}$ march.

The aim of both physical and psychological distress of volunteers is to bring them closer to real combat situations. At the end of the SCE, the volunteers performed workshops with tasks considered simple (to recover food released by parachute, prisoners' rescue, injured transportation, attacks on enemy stations, security patrol) and all workshops were held with monitored runtime, and division of tasks and team under the evaluation of trainers. Volunteers were offered complete R2 ration, military power supplied to servicemen during ground operations and also liquids (saline / water) (Table 1).

Table 1. Characterization performed at the 5th week after the start of CACTC during the first four days of military activity of the combat simulation exercise, Goiânia - GO, Brazil, 2015.

\begin{tabular}{lllll}
\hline \multirow{2}{*}{ Characterization CSE (5th week) } & \multicolumn{4}{l}{ Daily activities of the CSE } \\
\cline { 2 - 5 } & 1th day & 2 th day & 3 th day & 4 th day \\
\hline Liquid Intake & $4 \mathrm{~L}$ & $3 \mathrm{~L}$ & $2 \mathrm{~L}$ & - \\
Feeding & 1 Ration & $1 / 2$ Ration & $1 / 3$ Ration & - \\
Workshops physical activity continues & $\mathrm{R} 2$ & $\mathrm{R} 2$ & $\mathrm{R} 2$ & \\
Hours of sleep & yes & yes & yes & yes \\
March time walking 25 km / day & $2 \mathrm{~h}$ & $2 \mathrm{~h}$ & $1 \mathrm{~h}$ & -- \\
transportation of cargo (backpack and complete uniforms) & $25 \mathrm{~kg}$ & $25 \mathrm{~kg}$ & $25 \mathrm{~kg}$ & $25 \mathrm{~kg}$ \\
Body weight (measured scale) & yes & yes & yes & yes \\
Completing the questionnaire Borg 10 & yes & yes & yes & yes \\
Medical inspection & yes & yes & yes & yes \\
\hline
\end{tabular}

CACTC $=$ the COMANDOS Army Corporal Training Course. $\mathrm{L}=$ Liter; $\mathrm{Kg}=$ kilogram; $\mathrm{h}=$ hours. $\mathrm{R} 2=$ complete ration (dried food, breakfast, lunch and dinner, provided the military during ground operations). 
Workshops physical activity continues was composed by: Basic individual instruction; first aid; activities with special characteristics (orienteering in terrain, orienteering in river and fast action shot) and patrols (combat and rescue).

\section{Anthropometric evaluation}

Weight and height were measured for subsequent calculation of Body Mass Index (BMI). For this procedure a calibrated Filizola ${ }^{\circledR}$ scale was used for weighing the volunteers. All measurements were carried out individually by trained personnel following the procedures and recommendations issued by the World Health Organization (WHO,1995).

\section{Blood collection and analysis of muscle damage markers}

The participants were evaluated during the three days of the CSE, namely: first blood collection, on the first day in 8-hour fasting (T0); Second blood collection immediately after the march of $100 \mathrm{~km}$ (T1); and third blood collection 63 hours after the end of the CSE (T2). The blood samples were collected by qualified professionals, and then transported to the clinical laboratory of the medical center. In the pre-analytical phase, the samples were centrifuged and then aliquoted in 2 Eppendorf tubes with $3 \mathrm{~mL}$ of saline solution. An aliquot of saline solution was stored in a freezer at $20^{\circ} \mathrm{C}$ for subsequent analysis of concentrations of CPK, MB, CRP and AGPA, and another aliquot of saline solution was stored on refrigeration at $4^{\circ} \mathrm{C}$ for subsequent analysis of $\mathrm{LDH}$, since this enzyme degrades over the freezing conditions according to the manufacturer's instructions.

\section{Technical procedures of laboratory analysis}

The transport of the saline samples to the Laboratory of Biochemistry of the Army (Laboratório de Bioquímica do Exército - IPCFEx / $\mathrm{RJ})$ followed the recommendations of the resolution (RDC $\left.n^{\circ} 20,2014\right)$ from the National Agency for Sanitary Surveillance (Agência Nacional de Vigilância Sanitária - ANVISA), and there they were defrosted at room temperature, according to the analysis time in biochemical equipment BT 3000 Plus and mini VIDAS.

In BT 3000 Plus auto analyzer, daily washings and calibrations were performed and the samples were subjected to two levels of quality control $\mathrm{N}$ (normal) and $\mathrm{P}$ (pathological). While in the mini VIDAS equipment, procedures of standard curve reading and calibration were performed in order to let the equipment in conditions to receive the samples within quality control standards.

Serum concentrations of CPK were analyzed by biochemical auto analyzer, from the brand Wiener and model BT 3000, using the method CK - NAC UV / AA liquid (IFCC), serum concentrations of $\mathrm{LDH}$ were analyzed by the optimized UV method (SFBC), and serum concentrations of AGPA and CRP by immunoturbidimetric method. The $\mathrm{MB}$ was processed on the equipment from the brand Biomérieux and model miniVIDAS, and analyzed by Elfa methodology (Enzyme Linked Fluorescent Assay). In this study, the reference values of commercial kits suggested by manufacturers were used to mark out the basal samples.

\section{Statistical Analysis}

The normality of the variables was evaluated by the Kolmogorov-Smirnov test. Descriptive statistics were performed to characterize the participants and the values were expressed as mean \pm standard deviation or median and percentiles 25 and 75. To compare the variables analyzed in the three different times, an analysis of variance (ANOVA) was applied to repeated measures with post hoc Tukey's test to identify statistically significant differences. $\quad \mathrm{P}<0.05$ values were considered significant. Statistical analyzes were performed using the SPSS 20.0 for Mac®; Chicago USA.

\section{RESULTS}

This study enrolled 43 volunteer servicemen, aged between 19 to 24 years old (19 years median; 19-22, P25\% -P75\%, respectively), male, evaluated during CACTC, 1st ACB - GO (2015). Anthropometric data are presented in Table 2. In relation to total body mass, on average, at T0 the volunteers had significantly higher values than in $\mathrm{T} 1 \quad(74,4 \mathrm{~kg} \times 69,8 \mathrm{Kg} ; \mathrm{p}<0.05)$. However, significant differences were not observed from time $\mathrm{T} 2$ in relation to time $\mathrm{T} 1$ and $\mathrm{T} 0$. From the 43 military evaluated, 27 (63\%) were eutrophic individuals, $15(35 \%)$ overweight and only $1(2 \%)$ found oneself rated as obesity grade I.

Figure 2 presents the results of the perceived exertion evaluated by Borg Scale of 10 during the five moments of evaluation. In relation to day 1 , a significant increase in perceived exertion occurred on days 02,03 and 04 . No statistically significant differences were observed between day 01 and day 07. Besides that, the perceived exertion was, on average, significantly higher on day 04 , the last day 
of activities, if compared to all other days of evaluation.

Table 2. Anthropometric characteristics of the 43 volunteer military to CACTC, at times T0, T1 and T2, during military activity combat simulation exercise, Goiânia - GO, Brazil, in 2015.

\begin{tabular}{cccll}
\hline Variables & T0 & T1 & T2 & \multicolumn{1}{c}{$\boldsymbol{p}^{*}$} \\
\hline TBM $(\mathrm{kg})$ & $74,4 \pm 7,7$ & $69,8 \pm 7,6^{\mathrm{a}}$ & $73,3 \pm 7,7$ & $<0,05$ \\
Stature $(\mathrm{m})$ & $1,70 \pm 0,10$ & $1,70 \pm 0,10$ & $1,70 \pm 0,10$ & NS \\
IMC $\left(\mathrm{kg} / \mathrm{m}^{2}\right)$ & $24,6 \pm 2,5$ & $23,0 \pm 2,5^{\mathrm{b}}$ & $24,2 \pm 2,6$ & $<0,05$ \\
\hline
\end{tabular}

$p^{*}$ value obtained by ANOVA for repeated measures. ${ }^{a}$ Difference with T0. ${ }^{\mathrm{b}}$ Difference with T0 and T2.

Data are expressed as mean \pm standard deviation. CACTC $=$ the COMANDOS Army Corporal Training Course, TBM = total body mass; $\mathrm{BMI}=$ body mass index. $\mathrm{T} 0=$ baseline; $\mathrm{T} 1=72$ hours after the baseline; $\mathrm{T} 2=63$ hours after $\mathrm{T} 1$;

Table 3. Results of biochemical markers during the three times of evaluation from 43 military during military activity combat simulation exercise, Goiânia - GO, Brazil, in 2015.

\begin{tabular}{|c|c|c|c|c|c|c|c|}
\hline $\begin{array}{l}\text { Biochemical } \\
\text { markers }\end{array}$ & $\begin{array}{l}\text { Reference } \\
\text { values }\end{array}$ & T0 & $\mathbf{T 1}$ & $\mathbf{T} 2$ & $\Delta \mathrm{T} 1(\%)$ & $\Delta \mathrm{T} 2(\%)$ & $P *$ \\
\hline CPK (U/l) & $\begin{array}{l}24,0- \\
195,0\end{array}$ & $153,7 \pm 112,8$ & $1745,0 \pm 990,6^{\mathrm{a}}$ & $355,0 \pm 257,8$ & 1035,3 & 131,0 & $<0,001$ \\
\hline LDH (U/1) & $\begin{array}{l}230,0- \\
400,0\end{array}$ & $369,3 \pm 47,1^{\mathrm{b}}$ & $819,3 \pm 156,1^{b}$ & $504,8 \pm 89,7^{\mathrm{b}}$ & 121,8 & 36,7 & $<0,001$ \\
\hline Lactate $(\mathrm{mg} / \mathrm{dL})$ & $4,5-19,8$ & $30,0 \pm 7,5$ & $68,1 \pm 23,6^{\mathrm{a}}$ & $35,9 \pm 13,5$ & 127,0 & 19,7 & $<0,001$ \\
\hline $\mathrm{CPR}(\mathrm{mg} / \mathrm{l})$ & $0,0-50,0$ & $3,9 \pm 2,9$ & $11,0 \pm 12,8^{\mathrm{a}}$ & $5,7 \pm 5,8$ & 182,0 & 46,1 & $<0,001$ \\
\hline $\mathrm{Mb}(\mu \mathrm{g} / \mathrm{I})$ & $\begin{array}{l}10,0- \\
46,0\end{array}$ & $21,8 \pm 12,5$ & $180,6 \pm 136,0^{\mathrm{a}}$ & $34,5 \pm 15,1$ & 728,4 & 58,2 & $<0,001$ \\
\hline AGPA (mg/dl) & $\begin{array}{l}50,0- \\
120,0\end{array}$ & $73,8 \pm 14,0$ & $84,7 \pm 17,3^{\mathrm{a}}$ & $72,7 \pm 23,9$ & 14,7 & $-1,5$ & $<0,05$ \\
\hline
\end{tabular}

*p

value obtained by ANOVA for repeated measures. ${ }^{a}$ Difference with T0 and T2. ${ }^{\mathrm{b}}$ Difference with all others moments of evaluation. $\mathrm{CACTC}=$ the COMANDOS Army Corporal Training Course; $\mathrm{CPK}=$ Creatine phosphokinase LDH $=$ Lactate dehydrogenase, $\mathrm{CRP}=$ $\mathrm{C}$-reactive protein, $\mathrm{Mb}=$ Myoglobin; $\mathrm{AGPA}=$ alpha 1 -acid glycoprotein. Data are expressed as mean \pm standard deviation; $\mathrm{T0}=$ baseline; $\mathrm{T} 1=72$ hours after the baseline; $\mathrm{T} 2=63$ hours after $\mathrm{T} 1 ; \Delta \mathrm{T} 1$ calculated as: $(\mathrm{T} 1-\mathrm{T} 0) * 100 / \mathrm{T} 0)$ variation of $\mathrm{T} 1$ in relation to $\mathrm{T} 0$ and $\Delta \mathrm{T} 2$ calculated as: $((\mathrm{T} 2-\mathrm{T} 0) * 100 / \mathrm{T} 0)$ : variation of $\mathrm{T} 2$ in relation to $\mathrm{T} 0$.

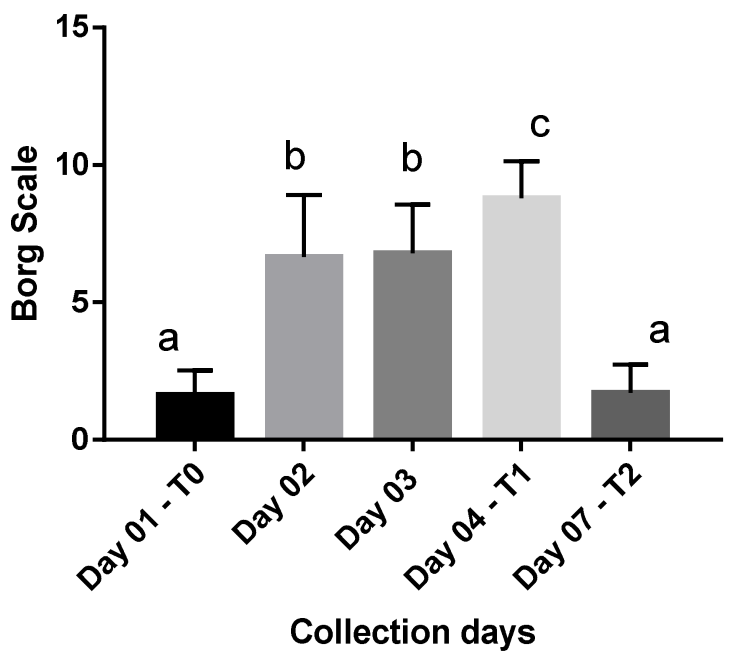

Figure 2. Borg Scale results of 43 volunteer servicemen assessed on the days of military activity combat simulation, Goiânia - GO, Brazil, in 2015. Different letters indicate statistically significant differences (ANOVA One-way, $\mathrm{p}<0.01$ ) on the Borg Scale 10 adapted among the days of evaluation. 


\section{DISCUSSION}

The present study aims to assess the behavior of muscle damage markers on servicemen during a military activity with a high degree of physical exertion.

It was observed a decrease in total body mass after 72 hours of activity (T1). This change in total body mass was probably a result from the loss of body fluids and the characteristics of physical activity. After 63 hours of rest, the total body mass values returned to the baseline observed, probably showing a recovery of body fluids.

A study performed by (ROMANOWSKI et al, 2015), observed the acute effect of physical activities in two different modalities (resistance training and aerobics) on body composition of young people, by using a technique of electrical bioimpedance. The evaluations were performed before and after the exercises proposed in the training protocol and result depicted that there was a significant decrease in body mass loss during the exercises.

The intensity of the physical activity was measured during all five days of the CSE, and always at the end of the activities by the application of the Borg Scale 10, which measures the perceived exertion. It was observed that the greatest results were distributed on days 02,03 and 04 . These results represent the most physically demanding days. It is important to highlight that the day 04 (last day of activity) reflects the day of greatest accumulation of exercise where volunteers depict the highest physical and emotional exertion, as well as the highest concentration of indirect markers when compared to all other evaluation days. In contrast, on day 01 (basal - T0) and day 07, after 63 hours of rest, statistically significant differences were not observed between the evaluated moments, showing full recovery after rest.

Regarding the muscle damage markers evaluated, this study revealed a 12 -fold increase in CPK levels at the time T1, compared to baseline T0 (1745,0 x 153,7;T1/T0), characterizing the responsivity of $\mathrm{CPK}$ on the more physically demanding time. This result indicates that this enzyme was significantly altered as a result of increased intensity of the physical activity performed during the CSE. It is important to highlight that after 63 hours of rest, the enzyme levels showed a significant reduction, on an average, returning to the values found at baseline $(355,0 \times 153,7 ; \mathrm{T} 2 / \mathrm{T} 0)$. Furthermore, in relation to the percentage change in $\mathrm{CPK}$ on the different periods evaluated, it could be observed that at time
$\mathrm{T} 1$ the enzyme ranged $1035,3 \%$ in relation to $\mathrm{T} 0$ and that this variation significantly decreased from time T1 to time T2 $(131,0 \%)$.

Similarly, an observational study in 499 male military recruits aged 18-45 years old, called to serve at Fort Benning in the US, showed that after two weeks of basic military training with great physical exertion, the CPK levels obtained on the $7^{\text {th }}$ day showed average values of $1356 \mathrm{IU} / \mathrm{L}(p<0$, 001 ) and that $26,5 \%$ of the volunteers had CPK levels 5 times higher than baseline (LANDAU; KENNEY et al. 2012).

In fact, (BAIRD et al, 2012), argue that the serum CPK concentrations are directly related to age, gender, ethnicity, muscle mass, type, load and intensity of exercise and rest time after exercise. The results presented in this study relating to the intensity and recovery time after intense activity are consistent with those described by (FOSCHINI et al,2008).

Studies suggest that the release of CPK and its removal on serum are directly dependent on the type of exercise, intensity, duration and the fitness level of those involved, these variables have a direct influence on enzymatic response on the increase of CPK in the blood stream once that this enzyme usually begins to rise within a few hours after the beginning of the exercise, peaks on 1 to 4 days and begins to decline from 3 to 8 days, (BAIRD; GRAHAM ET AL. 2012), (FOSCHINI; PRESTES et al. 2008) and (ROSSI; RAMOS et al. 2009).

Additionally, other markers studied followed the same behavior of CPK, thus, the concentrations of LDH and of acute phase proteins, myoglobin, CRP and alpha1-acid glycoprotein showed a significant increase at time $\mathrm{T} 1$ as compared to T0. Similar to the behavior of CPK, after the activity, the concentrations of the markers evaluated, with the exception of $\mathrm{LDH}$, returned to values close to the initial concentrations observed at T0. It is possible that the return to baseline concentrations occurred in this group because the volunteers had already adapted to the physical activity.

Some evidence show that the LDH cannot exceed the cell membranes and this only occurs when there is a disruption or changes in membrane permeability, where the cytosolic content increases in the blood stream (FOSCHINI; PRESTES et al. 2008)' (BRANCACCIO; LIPPI I et al. 2010). Another relevant issue is that, in adults, the LDH values are stable regarding age and sex, different from that observed with the CPK (BURTIS; ASHWOOD et al. 2008). 
Thus, LDH was the only marker that remained higher even after rest, this result is in agreement with the literature, which indicates that this enzyme is a good marker to monitor acutechronic cases, since the enzymatic behavior takes to 12 days to return to normal(BRANCACCIO; MAFFULLI ET AL. 2008).

In this context, in a study with soccer players, it was observed that $\mathrm{LDH}$ values remained high in face of the demands of the training (HOFFMAN; KANG et al. 2005). The study of (FOSCHINI; PRESTES et al. 2008) suggests this biomarker as great in monitoring activities that deal with acute or chronic muscle tissue damage, however, one limitation could be their lack of specificity, because it is distributed throughout the body, making it difficult to determine the source where the damage occurred. It is important to note that for $\mathrm{LDH}$, the strenuous physical activity exerts a small effect on this enzyme, what may lead to increases in the order of $25 \%$ to average values (BURTIS; ASHWOOD et al. 2008).

A study realized with elite soccer players evaluated the effect of exercise on the CPK and LDH markers, showing a peak in the concentrations of CPK and LDH 48 hours after the game. The authors suggested that a football match can cause muscle micro-trauma, leading to an increase of these markers in the bloodstream. Moreover, they also noted that the period for the normalization of $\mathrm{LDH}$ was lower compared to CPK, being 96 hours and 120 hours, respectively (ISPIRLIDIS; FATOUROS et al. 2008). As stated above, in this study the resting time was only 63 hours and was observed CPK concentrations in standardization, but not in the $\mathrm{LDH}$.

It is important to observe that the nature and intensity of stimulation may have different effect on individuals due to biological variability that each individual has in relation to the same stimulus (BURTIS; ASHWOOD et al. 2008). Another justification for not comparing the results is that cytoplasmic enzymes not always have the same enzymatic behavior; this fact is closely related to the nature of the physical activity. Thus you can observe different responses depending on the type, intensity and load of exercises (BRANCACCIO; MAFFULLI et al. 2008).

The myoglobin is a marker that attracts great interest when the subject matter is muscle damage and presents a potential nephrotoxic effect (MACHADO; ZINI, ET AL, 2012). The monitoring of $\mathrm{Mb}$ is very important during real activities and / or military training, which usually occur in unfavorable environmental conditions such as intense heat, high relative humidity, wearing military uniform, weapons overburden, large marches on foot over rough terrain and low intake of liquids. All of these conditions are favorable to the development of a rhabdomyolysis pathological framework, induced by intense physical effort (Update: EXERTIONAL RHABDOMYOLYSIS, 2015) and (ALPERS; JONES 2010).

In relation to myoglobin, our results showed a significant increase in the concentrations of this marker during the activity, but similar to the other markers, it also returned to similar levels as observed at baseline. On average, the responsiveness rate of time $\mathrm{T} 1$ was 9 times higher if compared to baseline. It is important to notice that the responsiveness rates were very different between individuals, the greater responsiveness rate observed was 28 times and the smaller one was 2 times the value observed at baseline.

However, even with a significant increase, no servicemen reached values above the blood limit as proposed in the (PREMRU et al. 2013) study. Notwithstanding, it is important to note that high levels of myoglobin into the bloodstream indicate high levels of myoglobinuria, when the protein is not completely reabsorbed by the renal tubules, causing a severe precipitation and leading to severe acute renal failure (STRASINGER 2009).

The acute phase proteins, CRP and AGPA are glycoproteins found in the blood circulation during stress and acute inflammatory processes, these glycoproteins have their production increased by the liver (SMITH, 2004; CECILIANE, et al 2002). The monitoring of these markers during the physical activity and their response to a strenuous exercise, allow us to estimate the inflammatory impairment of the body.

On average, the concentrations of these markers were higher at $\mathrm{T} 1$, but even then, the concentrations were not above the maximum reference limits established by the analysis kits. Thus, it seems that this glycoprotein (AGPA) is not a good inflammatory marker for acute phase (DEVLIN 2006).

In a resilience study realized with 2600 Marines and sailors who were sent to serve in combat in Iraq and Afghanistan, analysis pre and post occupation were conducted and the results revealed a direct relation between increased concentrations of CRP and interleukin- 6 in the military that developed post-traumatic stress disorder. It seems that this association is related to the disorder caused by acute inflammation due to deregulation in the stress axis resulting in a lack of 
inhibition of pro-inflammatory pathways (ERALY et al. 2014).

A study performed using animal models examined the effect of an acute and exhausting protocol of physical exercises on the inflammatory response biomarkers CRP and AGPA, compared to a control group. Given the results, an increase was observed in AGPA concentrations within six hours after the beginning of the exercise, after this period the concentrations began to decrease, however, compared to 24 and 48 hours there was a significantly increase (FERRUCCI, 2005). Similar behavior was observed with the PCR on the same protocol, except that the CRP initially showed a tendency to be higher after three hours of the start of the protocol, it reached higher concentrations after six hours and established a plateau in the times of $6 / 12 / 24 / 48 / 72$ hours with the appearance of a peak in the CRP concentration 48 hours after exercise has been completed.

During the four-day evaluation of the SCE, we observe the behavior of markers related to muscle and inflammatory damage. Throughout the activity it was observed an increase in the amount of exercises and consequently, a significant increase of these biomarkers in blood, probably due to micro traumas (rupture of the extracellular matrix and basal lamina and of the sarcolemma) which are intimately connected to the intensity of the effort (LAZARINE et al, 2009). However, after the rest period that lasted 63 hours, the concentration of most of the analyzed markers returned to their baseline values, this was due to the positive adaptation of skeletal muscle tissue and adjacent structures, a strategy used by the body to reorganize impaired morphology and metabolic part of myofibril (SMITH, 2004).

For logistical issues it was not possible to perform the Physical Fitness Test (Teste de Aptidão Física - TAF) immediately before the beginning of CACTC, because it is a very intensive training course and activities scheduled in discipline plan. Another important limitation is the inability to collect blood samples at shorter intervals during the execution of the course and follow the decay curve for enzymatic longer time in the post exercise.

\section{CONCLUSIONS}

Volunteers showed a significant increase in indirect markers of muscle damage in saline (CPK, LDH, myoglobin, PCR and AGPA) when subjected to intense physical exercise during the 72 hours of the SCE. Nevertheless, after 63 hours of the end of SCE, indirect markers of muscle damage analyzed returned to values equal to or lower than baseline levels with the exception of LDH still remained above the levels observed at the time $\mathrm{T} 0$.

This study made possible to understand the behavior of indirect markers of muscle damage during the COMANDOS Army Corporal Training Course. However, others studies are necessary, regarding to Training Courses such as: paratrooper, mountain, jungle warfare and others to try establish a possible range of reference values for this markers during military activities.

\footnotetext{
RESUMO: O exercício de simulação de combate é uma atividade militar, onde as atividades de combate caracterizadas por intensa atividade física são simuladas. O objetivo deste estudo foi descrever o comportamento dos marcadores indiretos de lesão muscular durante as atividades militares de simulação de combate com a realização de esforços físicos extenuantes. Este estudo foi realizado com militares voluntários $(\mathrm{n}=43$; faixa etária $=19-24$ anos $)$ do Curso de Formação de Cabos do Exército. Os biomarcadores foram avaliados na linha de base (T0), 72 horas após o início das atividades (T1) e 63 horas após o final da atividade de (T2). Uma análise de variância (ANOVA) para medidas repetidas, com teste post hoc Tukey, foi aplicada para identificar as diferenças estatisticamente significativas nas variáveis analisadas em momentos diferentes. $\mathrm{O}$ critério de significância adotado foi o valor de $\mathrm{p}<0,05$. Em média, a massa corporal total foi significativamente maior no T0 quando comparado a T1 $(74,4 \mathrm{~kg}$ x $69,8 \mathrm{Kg} ; \mathrm{p}<0,05)$. Em relação aos marcadores bioquímicos, em média, os níveis séricos foram significativamente maiores $(\mathrm{p}<0,001)$ em T1 quando comparados com T0 para: CPK, LDH, CRP, Mb e AGPA. Após 63 horas de descanso, em média, os níveis séricos dos marcadores bioquímicos (CPK, LDH, CRP, Mb e AGPA ) foram significativamente menores do que no momento T1. No entanto, após 63 horas a partir do fim da atividade, todas as variáveis avaliadas retornaram à linha de base, com a exceção do LDH, que, em média, manteve-se significativamente maior do que os valores observados no momento T0. Este estudo possibilitou compreender o comportamento dos marcadores indiretos de lesão muscular durante o Curso de Formação de Cabos COMANDOS. No entanto, outros estudos são necessários, com relação a cursos de formação, tais como: paraquedistas, montanha, guerra na selva, e outros, para tentar estabelecer uma possível faixa de valores de referência para estes marcadores durante as atividades militares.
}

PALAVRAS-CHAVE: Lesão muscular. Marcadores indiretos de lesão muscular. Atividade física intensa. 


\section{REFERENCES}

ALPERS, J. P.; JONES, J. R. L. K. Natural history of exertional rhabdomyolysis: a population-based analysis. Muscle Nerve, v. 42, n. 4, p. 487-491, 2010. https://doi.org/10.1002/mus.21740

AMERICAN COLLEGE OF SPORTS MEDICINE. Progression models in resistance training for healthy adults. Med Sci Sports Exerc, vol. 41, n. 3, p. 687-708, 2009.

https://doi.org/10.1249/MSS.0b013e3181915670

ANVISA. Agência Nacional de Vigilância Sanitária. 2014. Resolução da Diretoria Colegiada RDC no 20, de 10/04/2014: Dispõe sobre o regulamento sanitário para o transporte de material biológico humano. Diário Oficial da União, Poder Executivo, Brasília, DF, 11 abr. 2014. № 70, Seção 1, p. 67.

BAIRD, M. F.; GRAHAM, S. M.; BAKER, J. S.; BICKERSTAFF, G. F. Creatine-Kinase- and ExerciseRelated Muscle Damage Implications for Muscle Performance and Recovery. Journal of Nutrition and Metabolism, vol. 2012, 13 pages, 2012.

BANFI, G.; COLOMBINI A.; LOMBARDI G.; LUBKOWSKA, A. Metabolic markers in sports medicine. Adv. Clin. Chem. , vol. 56, n. 1, p. 1-54, Dec, 2012. https://doi.org/10.1016/B978-0-12-394317-0.00015-7

BORG, G. Escalas de Borg para a dor e esforço percebido. São Paulo: Manole, 2000.

BRANCACCIO, P.; MAFFULLI, N.; BUONAURO, R.; LIMONGELLI, F. M. Serum enzyme monitoring in sports medicine. Clin Sports Med, v. 27, n. 1, p 1-18, jan, 2008. https://doi.org/10.1016/j.csm.2007.09.005

BRANCACCIO, P.; LIPPI, G.; MAFFULLI. Biochemical markers of muscular damage. Clin Chem Lab Med, v. 48, n. 6, p. 757-767, 2010. https://doi.org/10.1515/CCLM.2010.179

BRASIL. Caderno de Instrução CI 20-10/3 - Exercício de Desenvolvimento da Liderança. M. d. D. E. Brasileiro, 2006.

BRASIL. Programa de Instrução Militar: Brasília (DF): Centro de Doutrina do Exército - COTER; 2014.

BRASIL. Manual de Campanha EB20-MC-10.350 Treinamento Físico Militar, Brasilia, 2015.

BURTIS, C. A; BRUNS, D. E.; ASHWOOD, E. R. Tietz Fundamentos de Química Clínica. Rio de Janeiro: Elsevier, 2008.

CECILIANI, F.; GIORDANO, A.; SPAGNOLO, V. The systemic reaction during inflammation: the acutephase proteins. Protein and peptide letters, v. 9, n. 3, p. 211-223, 2002.

https://doi.org/10.2174/0929866023408779

DEVLIN, T. M. Textbook of Biochemistry with Clinical Correlations. 6th Edn, New Jersey, Wiley-Liss. 2006.

ERALY, S.A. et al. MARINE RESILIENCY STUDY TEAM. Assessment of Plasma C-Reactive Protein as a Biomarker of PTSD Risk. JAMA Psychiatry, v. 71, n. 4, p. 423-431, 2014.

https://doi.org/10.1001/jamapsychiatry.2013.4374

FERRUCCI, D. L. Análise de parâmetros hematológicos, bioquímicos e inflamatórios em ratos submetidos a um protocolo de exercício exaustivo agudo. Campinas, SP: UNICAMP, 2005. Trabalho de Conclusão de Curso, Universidade Estadual de Campinas, Faculdade de Educação Física, 2005.

FOSCHINI, D. et al. Acute hormonal, immunological and enzymatic responses to a basketball game. Brazilian Journal of Kinanthropometry and Human Performance, v. 10, n. 4, p. 341-346, 2008. 
HENRY, J. B. Diagnóstico Clínico e tratamento por Método Laboratoriais. São Paulo: Manole, 2012.

HILL, O. T. et al. Rhabdomyolysis in the US Active Duty Army, 2004-2006. Med Sci Sports Exerc, v. 44, n. 3, p. 442-449, 2012. https://doi.org/10.1249/MSS.0b013e3182312745

HOFFMAN, J. R.; KANG, J.; RATAMESS, N. A.; FAIGENBAUM A.D.; Biochemical and hormonal responses during an intercollegiate football season. Med Sci Sports Exerc, v. 37, n. 7, p. 1237-1241, 2005. https://doi.org/10.1249/01.mss.0000170068.97498.26

ISPIRLIDIS, I. et al. Time-course of changes in inflammatory and performance responses following a soccer game. Clin J Sport Med, v. 18, n. 5, p. 423-431, 2008. https://doi.org/10.1097/JSM.0b013e3181818e0b

LANDAU, M. E. et al. Investigation of the relationship between serum creatine kinase and genetic polymorphisms in military recruits. Mil Med, v. 177, n. 11, p. 1359-1365, 2012.

https://doi.org/10.7205/MILMED-D-12-00086

LAZARIM, F. L. et al. The upper values of creatine kinase of professional soccer players during the Brazilian National Championship. J Sci Med Sport, v. 12, n. 1, p. 85-90, 2009.

https://doi.org/10.1016/j.jsams.2007.10.004

MACHADO, M. et al. Relationship of glomerular filtration rate and serum CK activity after resistance exercise in women. International urology and nephrology, v. 44, n. 2, p. 515-21, 2012.

https://doi.org/10.1007/s11255-011-9963-4

MAGALHÃES, A. A. F. Insuficiência Renal aguda em militares submetidos a esforços físicos extenuantes. Rio de Janeiro: EsSEx, 2008. Trabalho de Conclusão de Curso, Curso de Formação de Oficiais do Serviço de Saúde, especialização em Aplicações Complementares às Ciências Militares, Escola de Saúde do Exército, 2008.

MONTEIRO, D. U. et al. Rabdomiólise induzida por exercício físico: a necessidade do diagnóstico precoce. In: Simpósio de Ensino, Pesquisa e Extensão, 2011, Rio Grande do Sul, UNIFRA, RS.

WORLD HEALT ORGANIZATION. Physical status: the use and interpretation of anthropometry, WHO Expert Committee. Geneva: WHO technical report series, 1995.

PARR, J. J. et al. Residual Impact of Previous Injury on Musculoskeletal Characteristics in Special Forces Operators. Orthop J Sports Med, v. 3, n. 11, p. 1-7, 2015. https://doi.org/10.1177/2325967115616581

PREMRU, V.; KOVAČ, J.; PONIKVAR, R. Use of myoglobin as a marker and predictor in myoglobinuric acute kidney injury. Ther Apher Dial, v. 17, n. 4, p. 391-395, 2013. https://doi.org/10.1111/1744-9987.12084

GOMES, R.C.; ROCHA, G. S., COMERLATO, M. Relação entre Nível de Atividade Física e Desempenho no Teste de Avaliação Física de Militares. Journal of Physical Education, v. 142, p. 19-27, 2008.

KYLE, L. et al. Effect of an Acute Exercise Session on Body Composition Using Multi-Frequency Bioelectrical Impedance Analysis in Adults. Journal of Sports Science, v. 3, n. 4, 2015

ROSA, N. G. et al. Rabdomiólise - artigo de revisão. Acta Méd Port, n. 18, p. 271-281, 2005.

ROSSI, L. F.; RAMOS, L. A.M.; RAMOS, R. R.; ARAÚJO, A. R. C. Rabdomiólise induzida por esforço físico intenso com altos níveis de creatinoquinase. Revista da AMRIGS, v. 53, n. 3, p. 269-272, 2009.

SMITH, L. L. Tissue trauma: the underlying cause of overtraining syndrome? J. Strength and Conditioning Res, v. 18, n. 1, p. 185-93, 2004. https://doi.org/10.1519/00124278-200402000-00028 https://doi.org/10.1519/1533-4287(2004)018<0185:TTTUCO >2.0.CO;2 
STRASINGER, S. K. Uroanálise e Fluidos Biológicos. São Paulo: LMP, 2009

TRICOLI, V. Mecanismos envolvidos na etiologia da dor muscular tardia. Rev. Bras. Cien. e Mov. Brasília, v. 9, n. 2, p. 39-44, 2001.

U.S. ARMED FORCES. 2015 Update: Exertional rhabdomyolysis, active component, 2010-2014. MSMR, v. 22, n. 3, p. 22-25, 2015. 